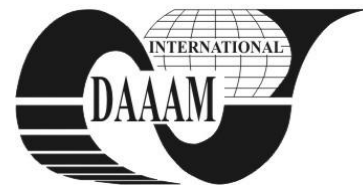

Annals of DAAAM for 2011 \& Proceedings of the 22nd International DAAAM Symposium, Volume 22, No. 1, ISSN 1726-9679 ISBN 978-3-901509-83-4, Editor B. Katalinic, Published by DAAAM International, Vienna, Austria, EU, 2011 Make Harmony between Technology and Nature, and Your Mind will Fly Free as a Bird Annals \& Proceedings of DAAAM International 2011

\title{
FIRMS' FINANCING FROM THE PERSPECTIVE OF MATHEMATICAL GAME THEORY
}

\author{
TUDOSE, M[ihaela] B[rindusa]; RADU, M[aria] \& RADU, D[orinel]
}

\begin{abstract}
The article aims to highlight the manner in which mathematical game theory is transposed in corporate finance, as firms seek to balance their own objectives (i.e. maximising market value by minimising the cost of raising capital) and those of investors (maximising returns on investments). The intended novelty of this paper lies in developing a model for optimising a firm's financial structure and assessing it in terms of investors' interests.
\end{abstract}

Key words: financial structure, optimisation criteria, cost minimisation, earnings maximisation

\section{INTRODUCTION}

The application of game theory to financial transactions focuses on two categories of stakeholders: users of financing (firms) and providers of financing (investors). The core of game theory consists in the strategy that a partner is able to build starting from the possible decisions of the other partner (each party has opposing interests). As far as the firm is concerned, its financial structure is designed based on certain criteria conducive to optimisation, such as minimising the cost of capital. From the investors' point of view, the strategy is focused on maximising returns on investments. When a firm's cost of capital is low, it is essential to ascertain not only the context that enabled it to achieve this objective but also the extent to which investors were able to achieve their goals. In fact, this is an instance of "cooperative game" (Stancu, 2007) in which both opponents seek to maximise their own chances of winning.

The main objective undertaken in this paper is to show how the mathematical game theory is transposed in the field of corporate finance. For these purposes, we will build a company finance structure optimisation model, based on the weighted average cost of capital criterion. We will simultaneously explain the extent to which investors (financing providers) are able to achieve their objectives.

\section{THE STATE OF THE ART IN THE FIELD}

The literature in the field features wide-ranging debates on firms' financing. They originate from the issue of choosing the most advantageous mix of capital (internal or borrowed) for the firm. In order to determine this combination (known as optimal financial structure) certain criteria have been identified that serve as benchmarks for optimisation (Toma \& Alexandru, 2003) as follows: the firm's rate of return; the cost of raising capital; maximum debt carrying capacity and the flexibility of the financial structure; risk; resource allocation; firm's objectives. Additionally, other criteria may be considered (Tudose, 2006) including: the size of the firm; the decline in shareholders' controlling power (in case of new share issues); technology risk (which may be offset by leasing equipment); adjusting repayment methods to the firms' financial constraints (certain reimbursement methods may be more convenient even if costlier); loan procedures; loan guarantees demanded.

Inaugurated by Emile Borel (1921) but comprehensively laid out only in 1944 by John von Neuman (a mathematician) and Oskar Morgenstern (an economist), the mathematical theory of games opened up a highly diverse research field.
Lately, we have observed increasing interest by finance researchers in "reassessing theories of finance against the background of game theory" (Stancu, 2007). With reference to the above, it must be emphasised that certain mathematicians have argued that "mathematical game theory has a broad applicability in the field of financial transactions, yet raises problems related to building specific functions and deliver concrete solutions for various models and classes of determinist or probabilistic financial transactions" (Purcaru, 1998).

\section{FINANCIAL STRATEGIES IN THE CONTEXT OF MATHEMATICAL GAME THEORY}

The value of a financial transaction - V(I,F) - is not perceived in similar fashion by investors (I) and the firm (F); whereas investors aim to maximise the rate of return of their investment, the firm seeks to minimise the cost of raising capital. Because investors and the firm do not act independently, one might argue that both parties will focus on a strategy that will diminish (as much as possible) the effects of the other party's strategy. A financial transaction (investment for investors, capital raising for firms) is optimal (or mutually advantageous, both for the firm and for the investors) if the strategies $m_{10}$ şi $m_{20}$ are in place to ensure that:

$$
\max _{m 1} \min _{m 2} V(I, F)=\min _{m 2} \max _{m 1} V(F, I)
$$

Approaching the issue from the firm's perspective, we acknowledge that it is possible to determine the optimal state (based on the cost of raising capital from different sources) by using linear optimisation models. In order to solve the linear programming problem, I will start from an admissible basic solution (forming a finite set) and will subsequently identify the solutions in order to minimise or maximise a particular function.

\section{OPTIMISING FINANCIAL STRUCTURE BASED ON THE COST OF FINANCING CRITERION}

\subsection{Limits to minimising the costs of capital used by a firm}

Minimising the cost of capital must not represent an objective in itself; rather this goal must be aligned with a broader focus on improving the financial structure and maximising the firm's value (Barbuta-Misu, 2009). The financial structure of a company which does not pay dividends (zero cost of equity) cannot serve as a reference for optimisation. A firm which pays a high number of dividends does not necessarily have an unfavourable financial structure (Onofrei, 2009). The concerns regarding increasing the rate of return on equity do not derail the company from the path of optimising its financial structure. Due to their higher return, a company's shares will be more attractive to investors and the increased share price will have "have a positive effect on the market value of the company" (Vernimmen, 2009). Nor can the cost of debt capital be considered as an absolute reference. Each creditor requires a target rate of return in exchange for providing access to his financing source. Considering that investors (creditors) have several options for investing their 
capital, they will opt for the investment type offering a risk premium, the rate of return in excess of a risk-free return rate.

\subsection{Modelling}

We propose the following steps for building the model:

- Defining the target function (required to perform the optimisation):

$f(x)=$ weighted average cost of capital $\rightarrow$ minimum, or

$$
f(x)=\frac{C_{p}}{C_{p}+C_{i}} k_{p}+\frac{C_{i}}{C_{p}+C_{i}} k_{i} \rightarrow \text { min. },
$$

where: $C_{p}=$ equity capital, $C_{i}=$ debt capital, $k_{p}=$ cost of equity capital, $k_{i}=$ real cost of debt capital (taking into account any tax shields).

As linear programming models only allow linear (minimum or maximum) optimisation functions, we must redefine the optimisation function. Consequently, by using $\boldsymbol{x}_{\boldsymbol{I}}$ to denote the ratio $C_{p} /\left(C_{p}+C_{i}\right)$ and $x_{2}$ for the ratio $C_{i} /\left(C_{p}+C_{i}\right)$, the optimisation function becomes:

$$
f(x)=x_{1} k_{p}+x_{2} k_{i} \rightarrow \min .
$$

- Defining the system of equations/inequalities specific to the financial structure to be optimized, in terms of the cost of financing

a) Firms have access to two main types of financial resources, own capital or equity and borrowed capital or debt, respectively. The first equation of the system reflects the financial structure:

$$
\frac{C p}{C p+C i}+\frac{C i}{C p+C i}=1
$$

According to the previously employed notation, the equation can be reformulated as follows:

$$
x_{1}+x_{2}=1
$$

b) Own capital - after making an investment financed exclusively by own capital, the level of equity cannot exceed the sum of the initial own capital $\left(C_{p 0}\right)$ and the value of the investment $(I)$. Consequently, the second component of the system will be an inequality:

$$
\begin{gathered}
C_{p} \leq\left(C_{p 0}+I\right) \text { or }\left(C_{p}+C_{i}\right) \frac{C_{p}}{\left(C_{p}+C_{i}\right)} \leq\left(C_{p 0}+I\right) \text { or } \\
\left(C_{p}+C_{i}\right) x_{1} \leq\left(C_{p 0}+I\right) .
\end{gathered}
$$

c) Borrowed capital - after the investment is made - cannot exceed the sum of the initial borrowed capital and the value of the investment (in case the investment was financed exclusively by borrowed capital). The third component of the system will also be an inequality:

$$
\begin{gathered}
C_{i} \leq\left(C_{i 0}+I\right) \text { or }\left(C_{p}+C_{i}\right) \frac{C_{i}}{\left(C_{p}+C_{i}\right)} \leq\left(C_{i 0}+I\right) \text { or } \\
\left(C_{p}+C_{i}\right) x_{2} \leq\left(C_{i 0}+I\right) .
\end{gathered}
$$

From the standpoint of the creditor/investor who seeks to maximise his profit, this transaction is only justified if it involves a premium aligned with the level of risk he is taking. Once loan is agreed, it is argued that both parties (the firm and the investors) have achieved their goals.

d) Borrowed capital - after the investment is made - cannot exceed double the value of own capital (a prerequisite for ensuring the survival of the company and its financial balance).

$$
C_{i} \leq 2 C p \text { or }\left(C_{p}+C_{i}\right) \frac{C_{i}}{\left(C_{p}+C_{i}\right)} \leq 2\left(C_{p}+C_{i}\right) \frac{C p}{\left(C_{p}+C_{i}\right)} \text { or }
$$

$$
\left(C_{p}+C_{i}\right) x_{2} \leq 2 x_{1}\left(C_{p}+C_{i}\right) .
$$

The inequality can be tested by factoring in the known amount of the projected investment; therefore it is not indispensable in defining the system of equations/inequalities.

- Defining the linear optimisation problem:

$$
\left\{\begin{array}{l}
x_{1}+x_{2}=1 \\
\left(C_{p}+C_{i}\right) x_{1} \leq\left(C_{p 0}+I\right) \quad f(x)=x_{1} k_{p}+x_{2} k_{i} \rightarrow \text { min. } \\
\left(C_{p}+C_{i}\right) x_{2} \leq\left(C_{i 0}+I\right) \\
x_{1}, x_{2} \geq 0
\end{array}\right.
$$

- Solving the problem. By incorporating in the model only two variables $\left(x_{1}\right.$ and $\left.x_{2}\right)$, the system may be solved either graphically or by using the primary simplex algorithm or based on the two-phase method, just as to the matrix of the equation system one may or may not add elementary transformations to construct a unit matrix (Reitano, 2010).

\subsection{Limits of the model and objectives for future research}

The model we developed is based on a single-criterion optimisation. In practice, the cost of capital is not the sole determining factor in financial decisions. Building a model that should enable a multi-criterion optimisation of the firm's financial structure will constitute afuture focus of research for us.

\section{CONCLUSIONS}

Firms' financing has been and continues to be a constant and key focus of research in the field of corporate finance. The study highlights the fact that, when viewed through the prism of the mathematical game theory, new dimensions of firms financing emerge. This new approach opens up new perspectives in terms of optimising firms' financial structure, as it serves to determine the finite set of potential strategies in order to reach the equilibrium state of the game.

\section{ACKNOWLEDGEMENTS}

This work was supported by the project "Post-Doctoral Studies in Economics: training program for elite researchers SPODE" co-funded from the European Social Fund through the Development of Human Resources Operational Programme 2007-2013, contract no. POSDRU/89/1.5/S/61755.

\section{REFERENCES}

Barbuta-Misu, N. (2009). The Financial Structure Influence on the Cost of Capital and Enterprise Value. Annals of "Dunarea de Jos" Galati, Fascicle I, Economics and Applied Informatics, years XV, no. 2 (Issue 2/2009), pp. 77-84, ISSN 1584-0409

Onofrei, M. (2009). Guvernanta financiara corporativa [Corporate Financial Governance], Editura Wolters Kluwer, ISBN 978-973-1911-63-2, Bucharest

Purcaru, I. (1998). Matematici financiare [Financial Mathematics], Editura Economica, ISBN 973-9198-10-4, Bucharest

Reitano, R. (2010). Introduction to Quantitative Finance, MIT Press, ISBN 978-026201369-7, Cambridge

Stancu, I. (2007). Finante [Finance], Editura Economica, ISBN 978-973-709-320-2, Bucharest

Toma, M., Alexandru F. (2003). Finante si gestiune financiara de intreprindere [Corporate Finance and Financial Management], Editura Economica, ISBN 973-590-771-2, Bucharest

Tudose, M. B. (2006). Gestiunea capitalurilor intreprinderii [The Management of Corporate Capital], Editura Economica, ISBN 978-973-709-263-2, Bucharest

Vernimmen P. et. al. (2009). Finance d'entreprise [Corporate Finance], $7^{\text {th }}$ edition, Dalloz, ISBN 978-2-247-080038, Paris 